\title{
Use of Local Wisdom (Purpusage) through Heart-to-Heart Communication in Settling of Social Conflicts in Karo, North Sumatra Indonesia
}

\author{
PUJI LESTARI \\ Universitas Pembangunan Nasional "Veteran" Yogyakarta, Indonesia \\ RAMA KERTAMUKTI \\ Universitas Islam Negeri Sunan Kalijaga Yogyakarta, Indonesia \\ POPPY RULIANA \\ STIKOM InterStudi Jakarta, Indonesia
}

\begin{abstract}
Refusal of refugee relocation policy due to the eruption of Mount Sinabung from the community members in Lingga Village, Karo Regency, in North Sumatra Province has created social conflict. This study aims to find a model of social conflict management through heart-to-heart local wisdom, known as communication purpusage in Karo, North Sumatra. This research uses a qualitative approach in order to further explore and understand the process of heart to heart basis of communication and local wisdom. Data collection techniques used in this research are observation and in-depth interviews on research subjects, more specifically the background of the conflict, the parties involved in the conflict, the impacts of the conflict, and the solutions adopted. The results of this study show that a heart-to-heart communication model in the Karo culture through a process of runggu (communication for peace) produces local wisdom of purpusage that effectively resolves the conflict. This research contributes in offering a new concept of heart-to-heart communication for resolving social conflicts using a local wisdom called purpusage. Heart-to-heart communication among all conflicting parties has created a sincere communication attitude, which tends to accept the situation, willingness to overcome the conflict, and a strong desire to live peacefully. Village Community of Lingga Karo in North Sumatra has agreed to emphasize on heart to heart communication because it is rooted in their local culture named runggu and purpusage. This research recommends that local wisdom can effectively be used as an effort to resolve social conflicts.
\end{abstract}

Keywords: Local wisdom, purpusage, communication from heart to heart, social conflict, Sinabung.

\section{INTRODUCTION}

Indonesia as a country surrounded by volcanoes (ring of fire) is faced with the risk of catastrophic volcanic eruptions in various areas with more than 83 mountains. One of the volcanoes that have returned to be an active one after 1600 has not erupted, is Mount Sinabung $(2,460$ meters) in North Sumatera. The mountain first erupted in 2010, then successively in 2013, 2014, 2018 (Islahudin, 2013; Kusumayudha, Lestari \& Paripurno, 2018; Santama, 2018; Wulandari, Sagala \& Sullivan, 2018). Beginning in May 2019, Mount Sinabung erupted and threw volcanic materials into the sky as high as 2,000 meters (Muhardiansyah, 2019).

Unpredicted eruption of the Mount Sinabung since 2010 has created a social disaster for people live in surrounding areas. This continuing eruption causes social and economic sufferings. People must be ready for evacuation every time the Mount Sinabung erupts, and 
some even hve been evacuated for up to seven years (Jamil, 2018). In anticipating a worse situation, since 2016, the government has launched "Self Relocation Program", which gives freedom to the victims of Mount Sinabung to determine locations for their new settlements that are safe from the eruption's coverage. Through this program, relocation costs are assisted by the Government (Kabrina \& Kusmanto, 2016).

The total residents of Lingga Village, Simpang Empat Subdistrict, Karo District, is 1904 Family Heads, which consist of 4967 inhabitants received the assistance cost, while 221 other Family Heads rejected the program. The rejection led to conflicts between villagers and police officers, which resulted in the death of one resident (Sinaga, 2016). Residents rejected Lingga village as an independent relocation area by moving four affected eruption villagers to Lingga Village, which was relatively safe from the eruption range of Mount Sinabung.

This study discusses conflict management by prioritizing the local wisdom of village communities combined with heart-to-heart communication to find common ground in resolving social conflicts. Communication among members of society is a fundamental process in building and maintaining resilient communities (Spialek \& Houston, 2017). The characteristics of villagers, who live communally, have close relationship each other's, become social capital in resolving social conflicts. Local wisdom becomes a shared reference for directing behavior of the people (Haryanto, 2014) and local wisdom also used to avoid throwing blame, throwing responsibility when a disaster occurs (Nayar, 2012). In this connection, this study aims to find a model of social conflict management through combining a careful communication with a local wisdom known as purpusage in Karo, North Sumatra.

In general, local wisdom has an important functions and roles in society, namely: (1) as a tool to maintain, protect and preserve natural resources on a regular basis; (2) human resource development; (3) development of culture and science; (4) as sources of trust and abstinence; (5) as a mean of forming and building people's unity; (6) as the foundation of ethics, morals, and political functions (Basyari, 2014). Local wisdom and traditional mechanisms are applied in land use and resource management in Karo, North Sumatra as a means of maintaining social and environmental order. Local wisdom is an integral part of Karo socio-cultural life. It is even passed on to the younger generations of Karo people. The elderly has knowledge of family history and shows a wise attitude in facing problems of the community. Local wisdom is passed on through informal media such as personal narratives in the form of experiences, hereditary family legends, myths, anecdotes, folk songs and sayings that contain meaning. Elderly of Karo expects young people to have experience and survival skills. Local wisdom is an inseparable part of the culture that is built in the community (Agatha, 2016).

\section{LITERATURE REVIEW}

Research on disaster communication by Moorthy, Benny and Gill (2018) showed that all disasters carry several types of communication problems. Problems that arise include external communication between victims and the community and internal communication between emergency response personnel and related agencies. Communities that face disasters and settle in the regions will be more difficult to control their behavior. It is important to understand the socio-cultural worldview and behavior of people in disaster management. Instilling culture of resistance has a greater chance to avoid casualties and 
unnecessary loss. Culture must be seen as a useful collection of resources, not as a barrier. Culture is believed to be able to embrace disaster because cultural knowledge produced by society is built on cultural rationality that is created continuously from time to time. The members of community are tending to ignore warnings when an actual disaster occurs, by being reluctant to heed official warnings for evacuation and forming fearless feelings. Most community members prefer to look at cultural values as their guidance during the disaster. This situation needs to be considered seriously in order to increase trust and reduce anger in disasters.

Communication and local wisdom are indeed integrated in rural communities across Indonesia. In Javanese rural communities, for example, it is known as "kentongan titir", in which most members of community shared the same meaning when they listen to particular sounds of kentongan. For example, if the kentongan is hammered repeatedly in a quick tone, it sends a message to villagers about the danger of flooding. Hearing the sound of kentongan in forms of clappers, the villagers were simultaneously preparing and guarding against a flood (Harmoko, 1986).

Research on local wisdom as an alternative disaster communication management in Mount Sinabung was conducted by Lestari et al. (2015). The results showed that people in the Mount Sinabung area adopted local wisdom in the form of (1) Karo Language; (2) Jambur (meeting place); (3) Philosophy, (4) Ecology; (5) Family system; and (6) Years of work. Local wisdom has been applied in Karo District, but does not include social conflict resolution.

In line with Lestari's research which explains local wisdom is used as communication management in disasters, Zulfadrim's research (Zulfadrim, Toyoda \& Kanegae, 2018) also concerns with the implementation of local wisdom in reducing the risk of natural disasters in West Sumatera. The results show that local wisdom can be applied as an effective tool for dealing with hazards and disasters. The Minangkabau community in terms of preventing and reducing the risk of disasters has developed a variety of ways, one of them with good adaptation preparation. Adaptation preparation is done by building traditional houses that have the ability to withstand earthquakes, floods, and attacks from wild animals. Another local wisdom in overcoming the impact of disasters in West Sumatra is mutual cooperation or mutual assistance to surrounding people. The Minangkabau area applies local wisdom in the form of traditional houses and mutual cooperation.

Other research that discusses the communication and construction of local knowledge (local wisdom) in rural Thai rice conducted by Genilo (2017) which emphasized that villages with relatively complex communication systems have extensive local knowledge and systems of practices. Community-based knowledge and perspectives in local wisdom have focused on the attention of the community, especially in terms of communication. The homogeneous small farming community in Thailand (the number one rice exporter in the world) utilizes communication to increase rice production, especially traditional communication. This research explores the role of communication in the formation of perspectives and the construction-management of knowledge in local practices, such as in rice farming. The ethnographic pictures of the two rice farming villages are carried out with the terms Baan Sap Som Boon (irrigation) in Chainat (Central Region) and Baan Hua Hae (rain) provinces in Ubon Ratchathani (Northeast Region) province. The results showed that Baan Sap Som Boon had extensive knowledge in methods and procedures of rice farming and complex community-based communication systems. Baan 
Hua Hae also practices more traditional ways of producing rice and divides time with other livelihood activities. In both villages, communication in local traditions played a central role in increasing crop production through facilitating the formation of collective definitions of rice farming, labor, economics, and agriculture-related institutions.

Subsequent research conducted by Christiawan (2017) on the role of local wisdom in controlling deforestation in Selatada Village, Buleleng Regency indicated that the embodiment of local wisdom to control deforestation and can coexist with forests, namely: (1) the form of ideas with awig-awig; (2) activities in the presence of pecalang; (3) artifacts with the existence of temples in the Forest.

In contrast to previous research conducted by Lestari, Zulfadrim, Genilo and Christiawan, this study seeks to add local wisdom to contribute to the resolution of social conflicts due to the eruption of Mount Sinabung in Lingga Village after the relocation of relocation which resulted in clashes with the victims. In addition, this research discovers a new concept in handling social conflicts, namely heart to heart communication. Simply put, heart-to-heart communication begins with recognizing the heart through feelings. The inability of a group of people to create peace in their environment is usually caused by their lack in understanding feelings of other individuals. The individual ego is concerned only with his own feelings, which causing dislikes towards other individuals. These negative feelings lead to negative thoughts towards others. Negative thoughts that produce negative attitudes also have an impact on antisocial behavior. This antisocial behavior is one of the causes of social conflict, as illustrated in Figure 1 . In this study social conflict was experienced by the people of Lingga Village with the security apparatus of Karo Regency, North Sumatra.

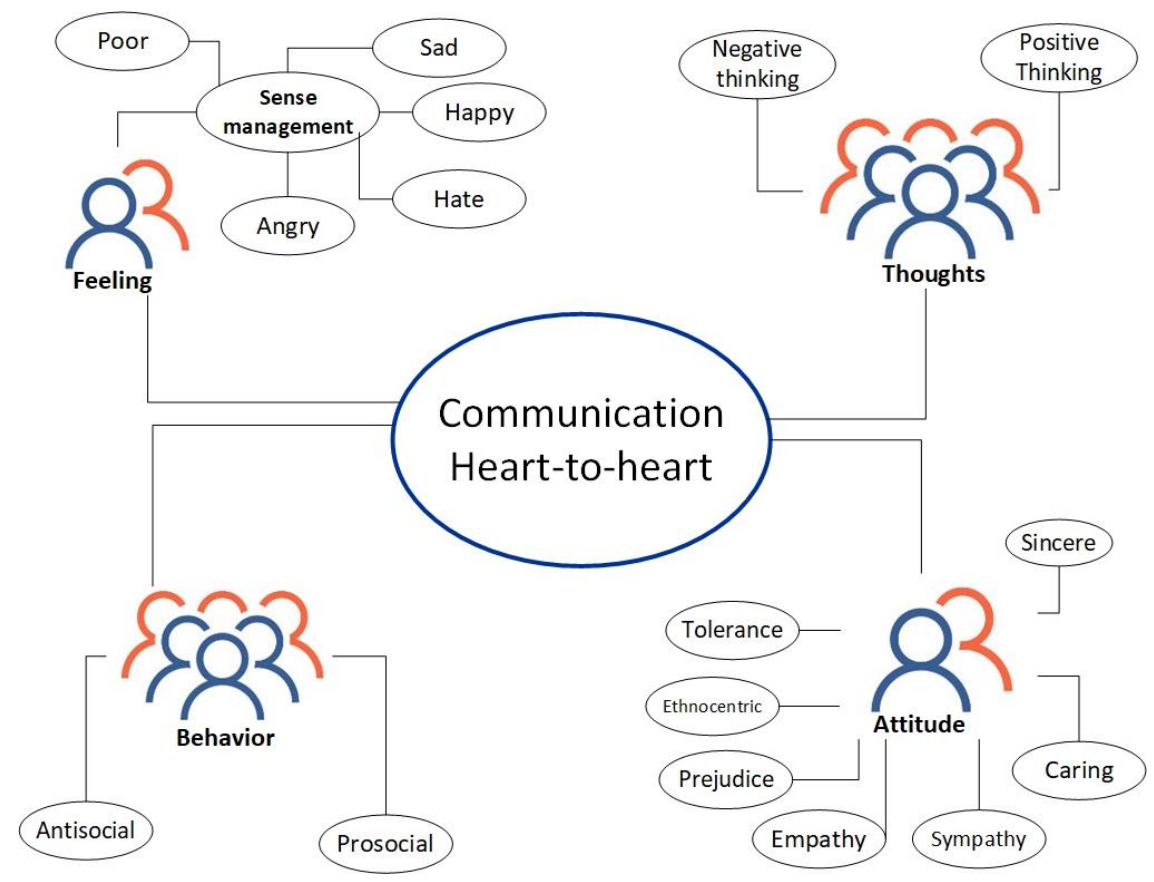

Figure 1: Heart to heart communication Source: Data processed by researchers, 2017-2019 
The concept of heart to heart communication is also reviewed by Nyonyorino (2014) through the concept of knowing your heart. Individuals who communicate with others often experience different interpretations and perceptions, which at the end causing different feelings. Individuals often assume that other individuals are the same as him, and ultimately it causes conflict. Conflict is addressed by recognizing the individual's heart first. The concept of recognizing the heart is an initial process for managing the heart as a foundation in responding to the provisions (Qodar) of man from his Lord so that it becomes a foothold for continued communication. The process of resolving social conflicts in Karo through local wisdom purpusage is also based on positive heart-to-heart communication. Heart-to-heart communication in this matter starts with positive thoughts for a peaceful life. There is mutual understanding between one party and another conflicting party. This understanding is meant by heart to heart communication according to the concept of heart.

Other research discusses conflict management related to the earthquake in Bantul, Yogyakarta, showing that conflicts occurred after the earthquake are caused by an inner pressure on the individual, jealousy over the assistance provided to residents, a different perception about assistance provided by the government, the community, and aid providers, as well as conflicts related to the reconstruction-rehabilitation process (Lestari, Susilastuti \& Hendariningrum, 2009). To resolve the conflict, the people of Bantul Regency refer to the Yogyakarta Local Cultural Values, including (1) Religio - Spiritual Values, (2) Moral Values, (3) Community Values, (4) Leadership Values and Government, (5) Values of Struggle and Nationality, and (6) Values and spirits of Yogyakarta. This research is in line with this study which examines the values of local wisdom to resolve social conflicts due to disasters. The difference lies in the values of Javanese local wisdom and Karo local wisdom.

Social conflict can also be studied using conflict management theory from the perspective of communication science, such as using communication crisis theory. A crisis is an unexpected situation that can create panic, uncertainty, and instability (Kriyantono \& McKenna, 2019). Understanding the communication crisis is a state of communication in society about the problem being faced (Juneza \& Purworini, 2016). The important thing in crisis communication is to provide a direct response when a crisis occurs, by giving an honest and open message directly or indirectly to the stakeholders (Tan, 2006). Crisis communication can also be interpreted as a process of conveying information relating to critical conditions and is carried out by stakeholders and related organizations to reduce the possible impacts (Purworini, Purnamasari, \& Hartuti, 2019).

There are three main principles in crisis communication (Prastya, 2011), namely (1) conveying quickly, which means providing an opportunity for stakeholders to find out the actual events. The information provided will quickly form a public perception that a problem can be controlled by the situation. Information given slowly can give the other conflicting party a chance to destroy the reputation with misinformation. Rapid information also has a weakness, namely the level of risk faced is higher. For example, information about the relocation problem in Lingga Village is quickly conveyed by the apparatus which can lead to conflicts among victims; (2) consistent, i.e. conveying the same message or information or one voice from various different sources. The impact of information about the relocation of Lingga Village which is less consistent leads to social conflicts; (3) openness, which is a controversial principle that arises due to different interpretations of the understanding of openness. 
There are two interpretations that emerge regarding the principle of openness, namely: (a) Interpretation of openness that is always ready to provide information or to communicate with stakeholders. If there is a reluctance in providing information to stakeholders, it can be said to be hiding something and it cannot handle the crisis; (b) A complete interpretation of openness, which is the informant giving and saying all the events that occurred. Different interpretations of relocation cause social conflict between the survivors and the government which results in a prolonged communication crisis. Crisis communication can be solved using local wisdom.

The nature of local wisdom can be interpreted as the attitudes and behavior of certain individuals and social entities in carrying out accommodation or interaction on an ongoing basis to explore cultural values and roots. Local wisdom has its own values, traditions, beliefs and norms that make a culture unique to one another (Mustafa \& Ahmad, 2019). Local knowledge can also be interpreted as a cultural heritage (legacy). Withn the tradition of history, it means ability to combinewith socio-political situation, ideology, or a system of modern culture (Budiantoro, 2018).

Conflicts that occur in the village of Lingga can be resolved through local wisdom purpusage. Purpusage is a cultural heritage and tradition of Karo that has been passed down for generations. The tradition of purpusage is shared when it has been recognized and experienced together with a meaning (Wan Mohd Ghazali, 2019). This local wisdom is proven to be able to overcome the communication crisis that is caused by various problems. Purpusage is preceded by runggu which is the local wisdom of the Karo custom. Research on runggu has been done by Lestari (Lestari, 2018) who found that there is a model for resolving social conflicts through local wisdom of Karo, namely Runggu.

Runggu is able to reconcile the community and parties involved in the conflict, as happened in the conflict in Kutarakyat Village due to a single accident: a truck carrying passengers displaced school children, overturning which left 40 children injured and one dead. The victim's family demands that the driver be sentenced to prison and compensates the victim's family. The driver's family is unable to provide compensation and asks the Karo Regency Regional Disaster Management Agency (BPBD) to resolve the issue. Karo BPBD also held Runggu. The victim's family and the driver's family make agreement. Conflict resolution (Figure 2) ends with a ceremony and traditional Karo dance that aims to maintain peace, balance in life, and rebuild the solidarity of the Karo community (Brahmana, Rochayanti \& Susilo, 2009). 


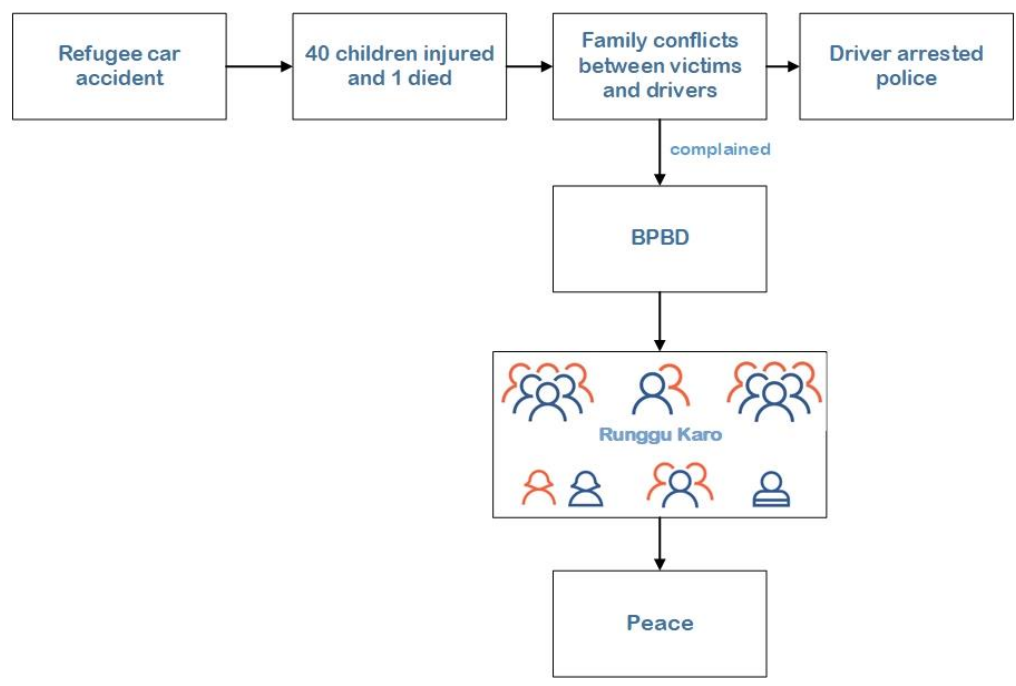

Figure 2: Accident Conflict Resolution Chart using Karo Runggu

Source: Data processed by researchers, 2017-2019

\section{METHODOLOGY}

This study uses a qualitative approach in the perspective of heart-to-heart communication and local wisdom. The research location is in the Village of Lingga, Karo Regency, North Sumatra. Research had been conducted from 2017 to 2019. The subjects of this study were Lingga Village apparatus, Lingga community members, Karo District Police, Chief of Karo Regency BPBD and staff, and Karo Traditional Leaders.

The object of this research is the management of social conflict among refugees of Mount Sinabung victims through communication in local wisdom of Purpusage. Data collection techniques used in this research are in-depth interviews, with research subjects related to the background of the conflict, the parties involved in the conflict, the impact of the conflict, and the solutions adopted; observations, which was conducted at the location of the social conflict in Lingga Village, the Police Station, and the Runggu and Purpusage locations; documentation, which was obtained from photographs during conflicts, and during Runggu and Purpusage; and limited discussion (Focus Group Disscusion) involving residents of Lingga Village, the Police, and Karo Regency BPBD. In-dept interviews were conducted with 10 people involved in the conflict, including 5 men and 5 women. 30 FGD participants were involved.

Table 1: Informants for in-depth interviews

\begin{tabular}{|c|c|c|}
\hline No & Name & $\begin{array}{c}\text { Gender } \\
\text { (M=Male; F=Female) }\end{array}$ \\
\hline 1 & BPBD (1) & $M$ \\
\hline 2 & BPBD (2) & $M$ \\
\hline 3 & BPBD (3) & $M$ \\
\hline 4 & BPBD (4) & $M$ \\
\hline 5 & BPBD (5) & $M$ \\
\hline 6 & BPBD (6) & $\mathrm{F}$ \\
\hline 7 & BPBD (7) & $\mathrm{F}$ \\
\hline 8 & BPBD (8) & $F$ \\
\hline 9 & BPBD (9) & $\mathrm{F}$ \\
\hline 10 & BPBD (10) & $\mathrm{F}$ \\
\hline
\end{tabular}


The data collected was analyzed by using the following stages: (1) Data Reduction, namely data analysis that directs, classifies, sharpens and discards data that is not needed. Data about social conflict is saved, while data about the amount of the relocation fund is reduced because it is not in accordance with the object of this study. (2) Presentation of Data, i.e. there is a collection of data compiled and allows the drawing of conclusions. Presentation of data generated can be in the form of text, matrices, graphs, and charts. Data about bronze, heart-to-heart communication and purpusage are presented in chart form for further analysis. (3) Withdrawal of Conclusions, i.e. the results obtained can be used for taking action. The results obtained are actions of purpusage as local wisdom to overcome social conflicts using a heart-to-heart communication approach.

\section{RESULTS AND DISCUSSION}

The eruption of Mount Sinabung in Karo District, North Sumatra, Indonesia in 2010 left many unresolved problems, one of which was the problem of handling refugees. Handling refugee relocation causes conflict due to the communication problem and rejection from the people of Lingga village. The communication conflict management strategy was used to resolve various problems between parties involved in the conflict. Based on the results of interviews with AS, informants who acted as the spokesperson of Lingga Village residents, said that conflict with the police began with the refusal of the refugee relocation policy. Initially, the developer of Mandiri Relocation promised to build a market in the region, not a relocation site. However, as time goes by, the area was actually used as a project to relocate the victims of Mount Sinabung eruption. According to AS, another reason that triggered the anger of people is the fact that the relocation program will increase the population to 1,600 households, while the area is only 1,600 hectares, with a current population of 1,000 households. The higher population density will increase a potential social conflict in the future (Fachrudin, 2016).

The results of observations and interviews (5 - 10 April 2017) regarding the conflict in Lingga Village with the Head Secretary of the BPBD, the Head of the Rehabilitation of Reconstruction, and the Head of the Lingga Village, the perpetrators of the land problem are members of the council and residents of Lingga Village. The Village Secretary stated that the issue of agreement from the village's head regarding the land that had not been settled was not allowed to be built. So that the refugees became scattered, around 160 families are buying land in the village of Lingga, and some are renting for 190 meters, with a price of Rp $100,000 /$ meter.

BPBD (1): “..."the residents want were different with the wishes of landowners, so the relocation program ended in chaos. A riot occurred when the developer dismantled the fence to build a relocation site. After that, the Lingga Village Secretary came to the police post to protest and followed by approximately 150 residents of Lingga Village. Lingga villagers protested by blocking the road in front of the police post, which causing a total traffic jam."

BPBD (2): "... Lingga community land was bought by the developer for the market, not relocation ..." 
BPBD (3): "... we are not disagreeing, but we feel coercive because the relocation policy was not notified to us ..."

BPBD (4): "... the community attacked because there were residents detained by the police station ..."

BPBD (5): "... the community continues to reject relocation, so there is chaos during development ..."

BPBD (6): "... we only want detailed notification without lies ..."

BPBD (7): "... chaos is not our fault, we just want our village not to be used as a relocation place."

BPBD (8): "... we have advised the developer so that our village does not need to be a relocation village."

BPBD (9): "... maybe between residents and the developer there has not been good communication, resulting in misunderstanding ..."

BPBD (10): "... relocation in the village of Lingga was carried out, because the government had difficulty in obtaining land, for forest use it had not yet obtained a permit. However, we were targeted because there was no agreement from the start. The village that was used for the market, apparently for relocation. We do not accept ..."

Eventually, residents had opened the road blockade. Hundreds of residents reappeared and shouted threatening sentences in front of the police post before setting fire to the police post and damaging heavy equipments (Indra, 2016). Five residents were arrested by the regional police (POLDA) to be charged for the fire. Meanwhile, residents wanted the police to release five arrested people. The protest was also supported by recidivists from other villages, who had been arrested by police for their involvement in criminal activities. This provocation was eventually created riots between residents and the police, resulting in one person died and another was in critical condition, and dozens of others were injured. The riots with casualties continued to the National Commission on Human Rights (Komnas HAM) and they called on the government to consider the cultural aspects of the local community (Ratnasari, 2016).

The results of the focus group discussion (FGD) on April 6, 2017, found that the root cause of the conflict was triggered by the problem of the independent relocation of the Mount Sinabung eruption survivors who would establish a village within the Lingga village. One of the FGD participants, Roma Sihaloho stated that:

Conflicts that occurred agreed to be immediately terminated using local wisdom, runggu and obtained an agreement between the conflicting parties to live peacefully. The agreement is based on heart-to-heart communication between Lingga residents and government officials. 


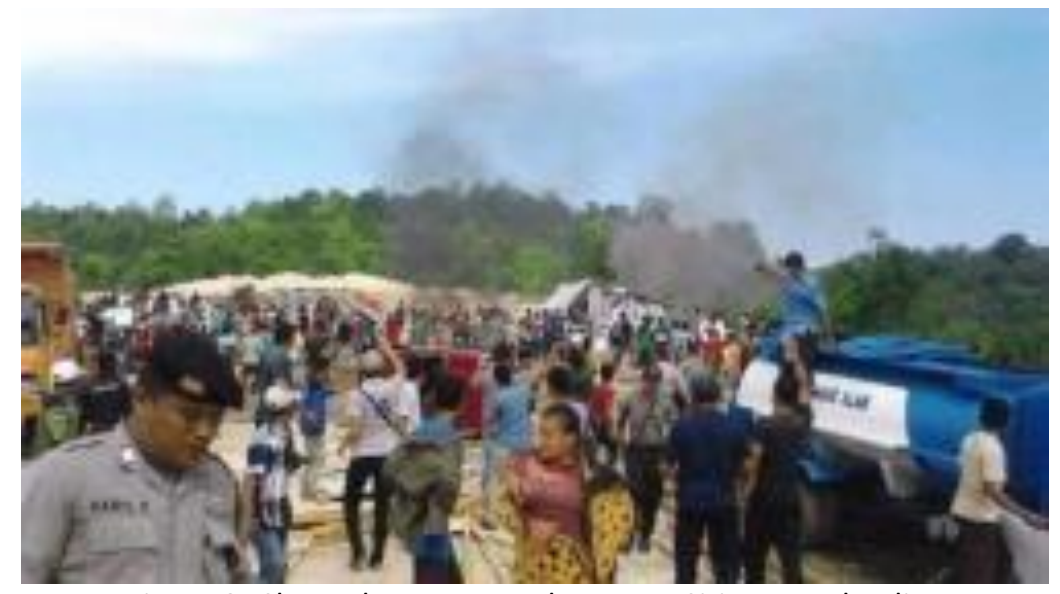

Figure 3: Chaos that Happens between Citizens and Police Source: (Nurdin, 2016)

This study found uniqueness in the resolution of social conflicts using local wisdom which is a characteristic of Karo culture in Lingga village. Lingga Village is a cultural village, so resolving conflicts is carried out using local wisdom to prevent cultural shifts. The local wisdom of Karo are Runggu and Purpusage.

Runggu is a customary law in the form of social communication process to resolve the conflict, while purpusage is customary law of conflict resolution as a result of runggu in the form of life in peace after the conflict. The conflict resolution models in Lingga Village are: (1) Runggu (Customary Law of the conflict resolution process), (2) Purpusage (Customary Law resulting from Runggu), (3) National Law (if the problem is not resolved by customary law). In this research, national conflict resolution was not conducted because the problem was resolved using a customary law. As for social conflict resolution process, a chart of Lingga village residents is presented in Figure 4. 


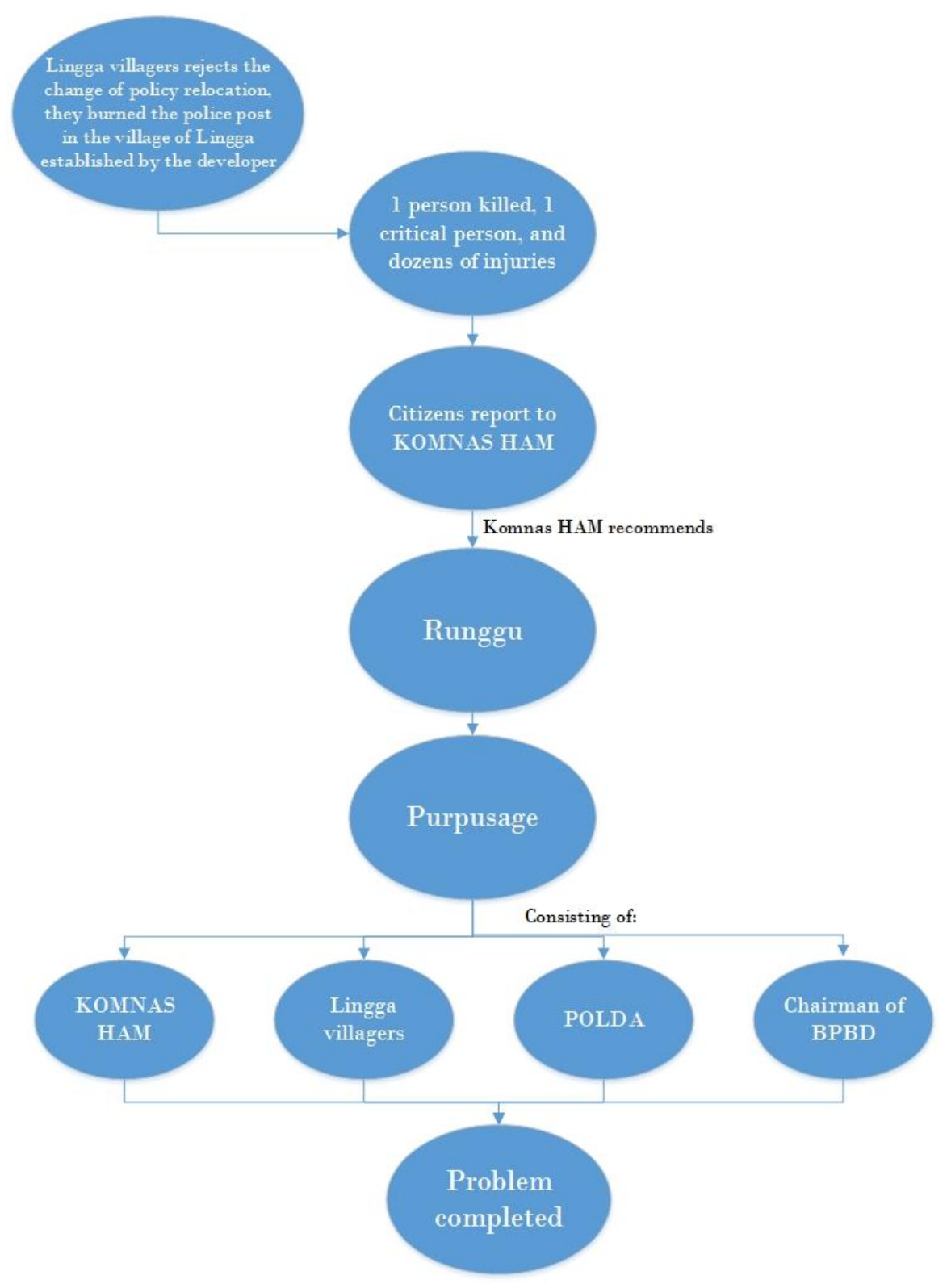

Figure 4: Social conflict resolution process chart Source: Data processed by researchers, 2017-2019

Local knowledge with purpusage preceded by runggu are able to solve social conflict by using a heart-to-heart communication approach. In Figure 5 is a process of runggu before purpusage at Lingga village community and the government was attended by the Head of Karo BPBDs and local government (PEMDA) Karo. Social conflicts that occur have different typologies and characteristics based on backgrounds and actors involved in the conflict. Local wisdom as a cultural treasure of the local community is expected to be a medium for conflict resolution as well as a basis for the formation of a culture of peace in society (Mudzakkir \& Sudrajat, 2016). 


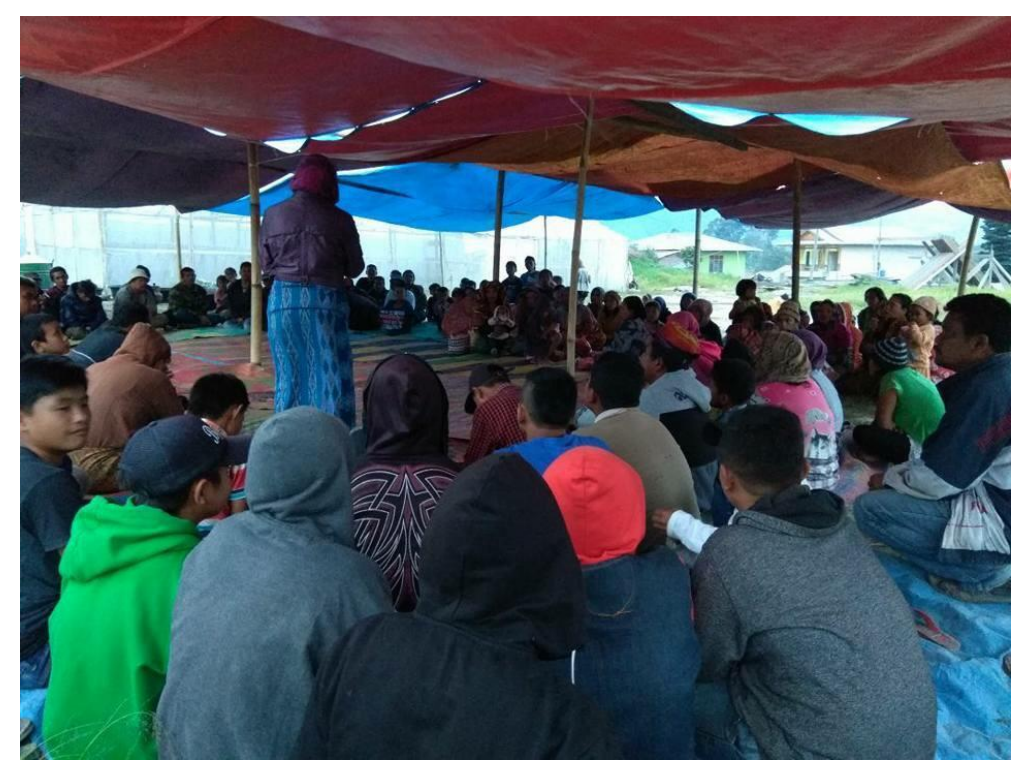

Figure 5: Runggu Process Before Purpusage in Lingga Village Source: BPBD Documentation (2017)

Heart to heart communication is applied at all levels of interpersonal, intrapersonal, group, organization, cross-cultural and mass communication. In an interpersonal communication, a heart that has a close with the Creator will cause and bring about a positive attitude. In an interpersonal communication, communication from heart to heart is manifested through the emergence of sympathy and empathy for other individuals. Group communication in the context of heart to heart communication can be done by one group with another group. Organizational communication in the context of heart-to-heart communication is realized by giving a positive aura to the members of the organization in order to produce good relationships. A heart-to-heart communication approach to crosscultural communication occurs when people who communicate have cultural differences, but sympathy and empathy accept cultural differences. Mass communication by using heart-based mass media will produce statements that give a positive feeling and are accepted by the group (Ruliana \& Lestari, 2019).

The principle of heart-to-heart communication, among others, can provide thoughts, attitudes, and positive behavior in dealing with other conflicting parties. The conflicting party is able to accept the attitude that giving up does not mean loser, but realizing that there are things that cannot be forced to be accepted by others. Apologizing does not always mean that the person is wrong and the other person is right, but that person's heart is worth more than his ego.

The basic assumption of heart-to-heart communication is when an individual realizes a positive sense of humanity towards other individuals and groups. In humans the role of conscience is very closely related to goodness. Many terms even say that "follow your conscience" and many speculate that conscience is the source of every good behavior that arises in the individual. According to the results of FGD with traditional leaders in the village of Lingga: 
We must yield not to continue the conflict with the consideration of conscience that we must live to understand each other. This attitude emerges from the mind that communication from heart to heart through runggu will achieve a peaceful life as taught by our ancestors.

Researchers actually see that the ability of conscience in creating individuals' awareness upon a positive sense of humanity towards other individuals will produce a peaceful attitude. This peace in heart-to-heart communication is realized through: (a) Sincere, means not calculating profit and loss as a priority. If all human activities are based on a sincerity, it will result in actions that are not strings attached. Getting used to behave sincerely can improve the quality of messages from the delivered communication because it can be conveyed effectively. Lingga Village community began to sincerely accept the conflict that occurred as a provisional of life. Sincerity is created with positive thoughts wherein the life to come. It requires security forces as the protector of the community. The security forces also sincerely accept the situation that has occurred and think positively for the sake of security and peace that has become the task of the authorities. (b) The hope of a problem being resolved is that every communicator (communicator, communicant) must have a purpose for what he conveys. Goals can be like the similarity of meaning in a message. Goals can be in the form of expectations to follow the communicator's instructions, or hope that a problem can be resolved properly. These expectations are what make the motives in communication differs. In a conflict, fear becomes a very strong barrier to create peace. The experience of threats and fears increases conservatism, prejudice, ethnocentrism, and intolerance. Collective fear and anxiety lead to the strengthening of in-group ties. Intergroup anxiety reduces motivation to contact or communicate between groups, thus hampering the course of peaceful conflict resolution. Fear has the potential to promote division.

Therefore, it is not surprising that there is a positive relationship between collective fear or anxiety and a willingness to make compromises (Halperin, 2014). In all of these studies, compromise was seen by participants as the most efficient way to reduce risk, and thus increased fear contributed to a more peaceful position. Positive emotions in the form of deliberation by expressing enthusiasm for peace will increase support for negotiations. Enthusiasm regarding this process has the potential to reduce conflict assessments and encourage a more optimistic view of the potential outcome of negotiations. These peace efforts were carried out as a way to end the practice of violence and stop casualties between the two parties and other communities affected by the conflict. The existence of activities that legally process suspects who commit acts of violence is a guarantee for the community to believe in the peace building. Handling with this kind of approach for temporary can work effectively, but it does not guarantee that conflict will not arise in the future. Empirical facts of a number of conflicts will be dammed if there is a serious legal handling of actions that are out of control.

In communication theory, there is the phrase "who says what, in which channel, to whom, and with what effect?" This sentence means that the most important aspects of communication and its effects are no exception. The effect can be a communicant response to the delivered message, or from the communication process that occurs before the message arrives. Expectation is the goal of communication, while a solved problem is the expected effect. To understand the relationship between society and the environment, local 
wisdom is a key in managing conflict and natural resources. Environmental history of Karo people is seen as an inseparable bond between agriculture and society. In other words, it describes a close relationship between space and natural resources. Land use and environmental resource management are linked to and influenced by the history and culture of the community, which is demonstrated by the continuity of culture through time and space. Although the environment and culture are dynamic, human development activities in capitalist mode are more a threat to the environment than an opportunity. Strategies for overcoming challenges and conflicts have been enshrined by rethinking indigenous knowledge and practicing them as an integral part of traditional wisdom. That is what happened in Karo, the government was considered to not understand the history of land that was cultivated by the community.

A sincere heart and positive thinking from the conflicting parties have created hope that the problem of communication crisis will be resolved soon. (c) A peaceful life is the goal of all living things. In heart-to-heart communication, the basic assumption of feeling at peace is when you include your conscience in your speaking, thinking, and behaving. As a result, everything will be in accordance with the purpose of peaceful living. The process can be described as follows: Individuals include a conscience when communicating, and then the message conveyed will have a strong meaning because it is based on the heart. Besides, individual will be more honest in himself, as a result, empathy, sympathy and other feelings will appear along with the use of the heart. Based on the study of human conscience, every human being has wrong and sin. Every human being has a hatred of others. If the person has a heart, this can reduce negative tendencies. A person's attitude determines the feedback he receives. A good heart will produce good feelings and thoughts. Good feelings and thoughts will produce good attitudes and actions. At the end, this research found that the social conflict in Lingga Village with the security forces in Karo Regency, North Sumatra, could be ended with local wisdom of purpusage which was based on heart-to-heart communication and led to peace between the conflicting parties. Humans are in fact social beings who cannot live alone. Humans must be interdependent with one another and need help from other individuals (Basyari, 2014).

Discussing conflict management based on local wisdom can be compared with research by Widiyowati (Widiyowati, Kriyantono, \& Dwi Prasetyo, 2018) regarding conflict in martial arts schools in Madiun - East Java. Widiyowati's research stated that the role of local wisdom in conflict management is very appropriate in realizing peace for the long term and spiritual aspects which are oriented towards welfare, life safety and happiness. The difference between this research and that of the research is that the novelty element in this study is conflict management based on the unique Karo ethnic local wisdom called Purpusage. Another novelty, this research resulted in the discovery of a new concept in the form of conflict management based on heart-to-heart communication that can create an atmosphere of peaceful community groups.

Conflict resolution through cultural runggu and purpusage relevant to the theory of organizational culture proposed by Geertz, Pacanowsky and O'Donnell-Trujillo (West \& Turner, 2008, p.319), in which they assumes the following points: (a) the Members involved in the organization creates and maintains a feeling of reality jointly owned organization. Its function is to get a better understanding about the values of an organization; (2) The use of symbols and their meanings are very important for organizational culture; (3) Many cultural variations that arise in different create different ways in interpreting certain actions. 


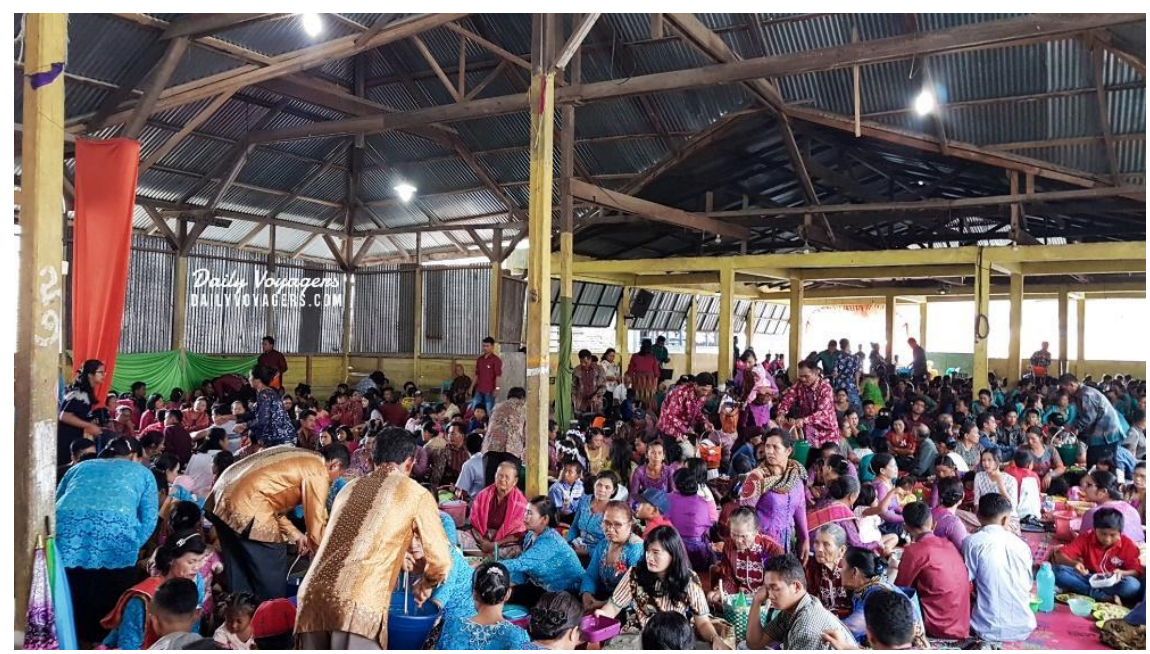

Figure 6: The Joint Eating Process

Source: Daily Voyagers, 2017

Research on the resolution of social conflicts in Karo using the culture of purpusage which was previously preceded by runggu, is a tradition that is passed down from time to time whenever there are problems that must be resolved in Karo District, North Sumatra. The culture according to the researchers is the values of local wisdom that is useful for creating peace in society. The development of technology, information and communication affected the younger generation, especially in making them aware of the presence of their local culture. It is a challenge for people to socialize local wisdom of runggu and purpusage among the next generation as means for resolving social conflicts effectively.

\section{CONCLUSION}

This research found a new concept of heart-to-heart communication in the resolution of social conflicts through employing local wisdom of purpusage in Karo District, North Sumatera. Heart-to-heart communication is carried out by the conflicting parties that are sincerely in accepting the situation, hopes that the problem can be resolved and lives peacefully. The concept of heart to heart communication not only applies in Karo District but can also be implemented to resolve various other social communication conflicts. This research supports the concept of heart-to-heart communication of Nyonyorino, namely the design of the heart is a process of acceptance of every communication that is conveyed to create further communication that is better and further improves the arrangement of the heart to avoid conflict.

Local wisdom can be found in various regions. Each region has its own local wisdom in solving social problems. This research recommends that the community maintain local wisdom as an effort to resolve social conflicts. Local wisdom increases the balance of natural resources. The people of Karo Regency in North Sumatra have non-violence knowledge values institutionalized in the social system. It shows that Indonesian people are able to establish a mechanism for conflict resolution as part of the social system before colonialism and modernism. Local wisdom as a marker of the identity of a community or community can be further explored in maintaining the integrity of a community. The identity of the community shows that the community has a culture and tradition of peace. Local wisdom can be interpreted as a dialogic arena to dilute the political exclusivity of identity inherent among various community groups. These efforts were made to build inclusiveness and 
reduce the potential for greater conflict. Local wisdom can foster the value of solidarity for a community, mutual appreciation; encourage the development of a sense of togetherness, and as a shared mechanism in preventing social conflict. Local wisdom can change the mindset and reciprocal relationships of individuals and groups, by positioning the culture as the most important aspect. Local wisdom is a form of unity of socio-cultural and socioreligious elements which aims to re-bond relations among people reduced by disputes in political, economic, and prestige values. The problem that often arises is that the mechanism of local peaceful conflict resolution in several places in Indonesia has been destroyed and some is left as a ritual of poor meaning.

\section{ACKNOWLEDGEMENT}

We would like to thank all parties involved in this research, especially DRPM Kemristekdikti, who funded this research through the 2017 - 2019 Applied Research in Higher Education (PTUPT) and Research Institute and Community Service (LPPM) of Universitas Pembangunan Nasional "Veteran" Yogyakarta, the subjects of this study, Lingga community members, Karo District Police, Chief and staff of Regional Disaster Management Agency (BPBD) of Karo Regency along with a team of Local Government Work Units (SKPD), NGOs, Karo Traditional Leaders, and research assistant.

\section{BIODATA}

Puji Lestari, is a senior lecturer at the Universitas Pembangunan Nasional "Veteran" Yogyakarta, Indonesia. Her research interests include disaster communication and intercultural communication. Email: puji.lestari@upnyk.ac.id

Rama Kertamukti, is a lecturer at Universitas Islam Negeri Sunan Kalijaga Yogyakarta, Indonesia. His research interests include Culture and Media Studies. Email: rama.mukti@uin-suka.ac.id

Poppy Ruliana is a lecturer at STIKOM InterStudi Jakarta, Indonesia. Her research interests in interpersonal and social communication. Email: poppyruliana30@gmail.com 


\section{REFERENCES}

Agatha, A. (2016). Traditional wisdom in land use and resource management among the Lugbara of Uganda: A historical perspective. SAGE Open, 6(3). doi: $10.1177 / 2158244016664562$

Ali, U. (2015). Teknik pengumpulan dan analisis data kualitatif. Retrieved on January 10, 2019, from http://www.pengertianpakar.com/2015/05/teknik-pengumpulan-dananalisis-data-kualitatif.html

Basyari, H. I. W. (2014). Nilai-nilai kearifan lokal (local wisdom) tradisi memitupada masyarakat Cirebon (Studi masyarakat Desa Setupatok Kecamatan Mundu). Edunomic, 2(1), 47-56.

Brahmana, E. B., Rochayanti, C., \& Susilo, M. E. (2009). Nilai-nilai gotong-royong dalam Tari Mbuah Page (Analisis semiotika nilai-nilai gotong-royong dalam Tari Mbuah Page pada acara adat Merdang-Merdem di Desa Perbesi Kecamatan Tigabinanga Kabupaten Karo Sumatera Utara). Jurnal IImu Komunikasi, 7(1), 84-91. Retrieved from http://jurnal.upnyk.ac.id/index.php/komunikasi/article/viewFile/8/8

Budiantoro, W. (2018). Literature review of spiritual care in Islamic cultural perspective. IBDA : Jurnal Kajian Islam Dan Budaya, 16(2), 350-368. doi: 10.24090/ibda.v16i2.1942

Christiawan, P. I. (2017). The role of local wisdom in controlling deforestation. International Journal of Development and Sustainability, 6(8), 876-888. Retrieved from https://isdsnet.com/ijds-v6n8-25.pdf

Fachrudin, F. (2016). Alasan warga lingga tolak relokasi pengungsi sinabung. Retrieved on November 25 , 2018,

from https://nasional.kompas.com/read/2016/08/01/17465931/ini.alasan.warga.lingga.tola k.relokasi.pengungsi.sinabung

Genilo, J. W. R. (2017). Communication and the construction of local knowledge in Thai rice farming villages. Millennial Asia, 1(2), 197-214. doi: 10.1177/097639961000100203

Halperin, E. (2014). Emotion, emotion regulation, and conflict resolution. Emotion Review, 6(1), 68-76. doi: 10.1177/1754073913491844

Harmoko. (1986). Komunikasi sambung rasa. Jakarta: Penerbit Sinar Harapan.

Haryanto, J. T. (2014). Kearifan lokal pendukung kerukunan. Analisa: Journal of Social Science and Religion, 21(2), 201-213. Retrieved from https://blasemarang.kemenag.go.id/journal/index.php/analisa/article/download/15/15 Indra, P. A. N. (2016). Pemindahan pengungsi Sinabung Ricuh, satu tewas. Retrieved on January 5, 2019, from https://tirto.id/pemindahan-pengungsi-sinabung-ricuh-satutewas-bwrX

Islahudin. (2013). Ini riwayat erupsi dan letusan Gunung Sinabung. Retrieved on January 7, 2019, from https://www.merdeka.com/peristiwa/ini-riwayat-erupsi-dan-letusangunung-sinabung.html

Jamil, A. I. (2018). Rakyat bicara: Derita Sinabung tiada akhir. Retrieved from https://www.inews.id/daerah/sumut/rakyat-bicara-derita-sinabung-tiada-akhir/57347

Juneza, R. R. D., \& Purworini, D. (2016). Respon para disabilitas terhadap komunikasi krisis BPBD (Badan penanggulangan bencana daerah) dan Tim SAR Klaten tahun 2016. Jurnal Profetik, 10(1), 80-96. doi: 10.14421/pjk.v9i1.1192 
Kabrina, C., \& Kusmanto, H. (2016). Kebijakan relokasi pengungsi dan konflik (Studi tentang formulasi kebijakan relokasi pengungsi Gunung Sinabung berkaitan dengan konflik Desa Lingga Kabupaten Karo tahun 2016). Repositori Universitas Sumatera Utara. Retrieved from http://repository.usu.ac.id/handle/123456789/65088?show=full

Kriyantono, R., \& McKenna, B. (2019). Crisis response vs crisis cluster: A test of situational crisis communication theory on crisis with two crisis clusters in Indonesian Public Relations. Jurnal Komunikasi: Malaysian Journal of Communication, 35(1), 222-236. doi: 10.17576/jkmjc-2019-3501-15

Kusumayudha, S. B., Lestari, P., \& Paripurno, E. T. (2018). Eruption characteristic of the sleeping volcano, Sinabung, North Sumatera, Indonesia, and SMS gateway for disaster early warning system. IJG: Indonesian Journal of Geography, 50(1).

Lestari, P., Susilastuti, DN. Rr., \& Hendariningrum, R. (2009). Manajemen konflik berbasis budaya lokal sebagai upaya meningkatkan jati diri bangsa Indonesia. Journal Ikatan Sarjana Komunikasi Indonesia, I(1), 73-96. Retrieved from http://eprints.upnyk.ac.id/14663/

Lestari, P. (2018). Cultural communication "Runggu" in disaster conflict. In, Multiple platform in transformative public relations, cultural and tourism (pp. 359-369). Palembang: ASPIKOM Buku Litera. Retrieved from https://www.dropbox.com/s/Ircuoabanhthm3o/BUKUAICCON_MULTIPLEPLATFORM.p $\mathrm{df} ? \mathrm{dl}=0$

Lestari, P., Eko, T. P., \& Sari, B. K. (2015). Local wisdom as alternative of disaster communication management in Mount Sinabung, Karo regency, North Sumatera, Indonesia. The Indonesian Journal of Communication Studies (IJCS), 8(1), 101-111. Retrieved from http://eprints.upnyk.ac.id/3416/

Moorthy, R., Benny, G., \& Gill, S. S. (2018). Disaster communication in managing vulnerabilities. Jurnal Komunikasi: Malaysian Journal of Communication, 34(2), 51-66. doi: 10.17576/jkmjc-2018-3402-04

Mudzakkir, M., \& Sudrajat, A. (2016). Resolusi konflik berbasis kearifan lokal di Jawa Timur: Sebuah tinjauan awal. Seminar Nasional "Revitalisasi Kearifan Lokal untuk Membangun Martabat Bangsa". Surabaya: Jurusan Pendidikan Sejarah FISH UNESA.

Muhardiansyah, Y. (2019). Setelah 11 bulan "tidur", Gunung Sinabung kembali erupsi lagi. Retrieved from https://www.merdeka.com/peristiwa/setelah-11-bulan-tidur-gunungsinabung-kembali-erupsi-lagi.html

Mustafa, B. A., \& Ahmad, A. L. (2019). Adaptasi antarabudaya penghijrahan pelajar Malaysia ke negara Asia. Jurnal Komunikasi: Malaysian Journal of Communication, 35(2), 18-34. doi: 10.17576/JKMJC-2019-3502-02

Nayar, P. K. (2012). Disaster communications media, crisis and representation. Journal of Creative Communications, 7(1). doi: 10.1177/0973258613501051

Nurdin, W. (2016). Kronologis lengkap kerusuhan warga dan polisi di Kabupaten Karo. Retrieved on January 17, 2019, from http://www.tribunnews.com/regional/2016/07/30/kronologis-lengkap-kerusuhanwarga-dan-polisi-di-kabupaten-karo

Nyonyorino. (2014). Komunikasi hati. Indonesia: Elex Media Komputindo.

Prastya, N. M. (2011). Komunikasi krisis di era new media dan social media. Jurnal Komunikasi UII, 6(1), 1-20. Retrieved from http://www.jurnal.uii.ac.id/jurnalkomunikasi/article/view/6374/5734 
Purworini, D., Purnamasari, D., \& Hartuti, D. P. (2019). Crisis communication in a natural disaster: A chaos theory approach. Jurnal Komunikasi: Malaysian Journal of Communication, 35(2), 35-48. doi: 10.17576/JKMJC-2019-3502-03

Ratnasari, Y. (2016). Relokasi pengungsi Sinabung patut pertimbangkan aspek adat. Retrieved on January 5, 2019, from https://tirto.id/relokasi-pengungsi-sinabung-patutpertimbangkan-aspek-adat-bzKB

Ruliana, P., \& Lestari, P. (2019). Teori komunikasi. Jakarta: PT RajaGrafindo Persada.

Santama, J. (2018). Kembali erupsi, Gunung Sinabung semburkan abu vulkanik 3,8 km. Detik.com. Retrieved on January 7, 2019, from https://news.detik.com/berita/d3885401/kembali-erupsi-gunung-sinabung-semburkan-abu-vulkanik-38-km

Setyadi, Y., Sarwoprasodjo, S., \& Muljono, P. (2016). Framing relokasi dan komunikasi risiko bencana erupsi Gunung Merapi (Studi kasus Desa Glagaharjo, Kecamatan Cangkringan, Kabupaten Sleman, DIY). Jurnal Komunikasi Pembangunan, 14(2), 109-119.

Sinaga, S. N. (2016). Penolakan pembangunan relokasi warga Sinabung berujung rusuh. Retrieved from https://www.liputan6.com/news/read/2565344/penolakanpembangunan-relokasi-warga-sinabung-berujungrusuh?utm_expid=.9Z4i5ypGQeGiS7w9arwTVQ.0\&utm_referrer=

Spialek, M. L., \& Houston, J. B. (2017). The development and initial validation of the citizen disaster communication assessment. Communication Research, 1(22). doi: 10.1177/0093650217697521

Tan, E. L. J. (2006). Singapore Airlines: A study in exemplary crisis communication. Wichita State University. Retrieved from https://soar.wichita.edu/bitstream/handle/10057/339/t06028.pdf?sequence $=4$

Wan Mohd Ghazali, W. N. (2019). Islam as the state ideology: Exploring from Gramsci's notion of power, culture and ideology. Jurnal Komunikasi: Malaysian Journal of Communication, 35(1), 338-352. doi: 10.17576/jkmjc-2019-3501-22

West, R., \& Turner, L. H. (2008). Pengantar teori komunikasi analisis dan aplikasi. (Terjemahan Maria Natalia Damayanti Maer, Ed.) (3rd ed.). Jakarta: Salemba Humanika.

Widiyowati, E., Kriyantono, R., \& Dwi Prasetyo, B. (2018). Model manajemen konflik berbasis kearifan lokal: Konflik perguruan pencak silat di Madiun - Jawa Timur. Jurnal Komunikator, 10(1), 34-47. doi: 10.18196/jkm.101004

Wulandari, Y., Sagala, S. A. H., \& Sullivan, G. B. (2018). The role of community - Based organization in disaster response at Mt. Sinabung. IOP Conference Series: Earth and Environmental Science, 158(1). doi: 10.1088/1755-1315/158/1/012035

Zulfadrim, Z., Toyoda, Y., \& Kanegae, H. (2018). The implementation of local wisdom in reducing natural disaster risk: A case study from West Sumatera. The 4th International Seminar on Sustainable Urban Development (Vol. 106). IOP Conference Series: Earth and Environmental Science. doi: 10.1088/1755-1315/106/1/012008 